\title{
EVALUASI PENERAPAN PPH FINAL PP 46 TAHUN 2013 PADA PEDAGANG TENANT METROPOLITAN MALL BEKASI
}

\author{
Nurwati ${ }^{1}$; Adi Rizfal Efriadi ${ }^{2}$ \\ Institut Teknologi dan Bisnis Ahmad Dahlan Jakarta \\ watisyam77@gmail.com'; hadirizfal2009@yahoo.com²
}

\begin{abstract}
ABSTRAK
Penelitian ini dilakukan untuk mengkaji penerapan PPH Final PP 46 Tahun 2013 yang diterapkan kepada pedagang tenan di Metropolitan Mall Bekasi, serta mengevaluasi penerapan dan perhitungan PPH Final PP 46 Tahun 2013 apakah sudah sesuai dengan Peraturan Perpajakan. Pendekatan penelitian yang digunakan adalah pendekatan kuantititif dengan analisis uji validtas, reliabilitas, normalitas, multikolinearitas dan uji T dengan menggunakan software SPSS. Dalam penelitian ini studi literature dilakukan melalui pengkajian literature seperti peraturan perundang-undangan, artikel-artikel, buku-buku, baik di media cetak maupun elektronik yang ditulis oleh ahli perpajakan berkaitan dengan pokok permasalahan yang ada dan akan disajikan sebagai landasan dalam menganalisis pokok permasalahan dalam penelitian ini. Hasil pengujian instrument dalam penelitian ini menujukkan bahwa data dalam penelitian valid, reliabel dan berdistribusi normal. Hasil penelitian menunjukkan bahwa tidak ada pengaruh yang signifikan antara pemahaman wajib pajak terhadap kepatuhan pajak. Semakin tinggi atau rendahnya pemahaman wajib pajak maka tidak akan berpengaruh terhadap kepatuhan wajib pajak membayar pajaknya. Implementasi self assesment system berpengaruh positif signifikan terhdap kepatuhan terhadap pajak. Semakin mudah implementasi Self Assesment System maka tingkat kepatuhan wajib pajak juga akan tinggi. Persepsi wajib pajak tidak memiliki pengaruh terhadap kepatuhan pajak. Semakin tinggi atau rendahnya pemahaman persepsi wajib pajak maka tidak akan berpengaruh pada kepatuhan terhadap pajak. Tidak berpengaruh sanksi terhadap kepatuhan pajak. Semakin tinggi atau rendahnya sanksi yang diterapkan, maka tidak akan berpengaruh terhadap kepatuhan wajib pajak.
\end{abstract}

Kata Kunci : PPh Final PP 46 Tahun 2013, Pedagang Tenant Metropolitan Mall

\section{ABSTRACT}

This research was conducted to examine the implementation of PPH Final PP 46/2013 applied to tenant traders at Metropolitan Mall Bekasi, as well as to evaluate the implementation and calculation of PPH Final PP 46/2013 whether it is in accordance with the Taxation Regulations. The research approach used is a quantitative approach with analysis of the validity test, reliability, normality, multicollinearity and T test using SPSS software. In this research, literature study is carried out through literature review such as legislation, articles, books, both in print and electronic media written by tax experts related to existing issues and will be presented as a basis for analyzing the main problems in this research. The results of instrument testing in this study indicate that the data in the study are valid, reliable and normally distributed. The results showed that there was no significant influence between the understanding of taxpayers on tax compliance. The higher or lower the understanding of the taxpayer, the less it will affect the taxpayer's compliance in paying his taxes. The implementation of the self assessment system has a significant positive effect on tax compliance. The easier the implementation 
of the Self Assessment System, the higher the level of taxpayer compliance. Taxpayers' perceptions have no effect on tax compliance. The higher or lower the understanding of taxpayers' perceptions, it will not affect tax compliance. Has no effect on sanctions on tax compliance. The higher or lower the sanctions applied, it will not affect taxpayer compliance.

Keywords: PPh Final PP 46 Year 2013 and tenant traders of Metropolitan Mall

Diterima: 11 September 2020; Direvisi: 21 September 2020; Diterbitkan: 1 Oktober 2020

\section{PENDAHULUAN}

Sektor Pajak merupakan sumber pendapatan yang sangat signifikan bagi Pemerintahan Republik Indonesia dengan sistem dan Peraturan yang terus diperbaharui dan disempurnakan dengan tujuan mempermudah semua pihak, baik pihak pemerintah sebagai pemungut Pajak maupun Wajib Pajak dalam menjalani kewajibannya.

Pemerintah Kota Bekasi dan Kantor Pelayanan Pajak Kota Bekasi belum maksimal mengadakan sosialisasi kepada para pedagang UKM tentang Pajak Penghasilan (PPh) Final PP 46 tahun 2013. Sebagian besar para pedagang UKM banyak yang tidak mengetahui atauapun tidak memahami secara benar tentang PPH Final PP 46 tahun 2013. Padahal potensi pajak kepada wajib pajak pedagang UKM cukup tinggi sebagai Pendapatan Asli Daerah (PAD) Kota Bekasi.

Sosialisasi kepada para pedagangan UKM tentang PPH Final PP 46 tahun 2013 diharapkan dapat meningkatkan PAD Kota Bekasi, namun apabila sosialisasi tidak maksimal yang dilakukan oleh pemerintah Kota Bekasi dan Kantor Pelayanan Pajak, dikhawatirkan akan menurunkan PAD Kota Bekasi serta menurunkan target wajib pajak.
Penurunan $\mathrm{PPh}$ Final dengan tarif pajak $0,5 \%$ kepada para pedagang UKM diharapkan bisa mematuhi kewajiban perpajakannya dengan lebih baik. Pemerintah juga mendorong peran serta masyarakat untuk terlibat membuka usaha dan UKM berkontribusi memajukan roda perkeonomian dan perdagangan dalam upaya membuka lapangan pekerjaan, meningkatkan kesejahteran kularga dan masyarakat serta negara.

Penelitian ini dilaksanakan pada pedagang tenant di Metropolitan Mall Bekasi berstatus UKM yang berpenghasilan menengah. Dalam hal pemenuhuan kewajiban pajaknya, pedagang tenant di Metropolitan Mall Bekasi mengikuti regulasi dalam proses tax compliance baik pembayaran maupun pelaporannya termasuk mengikuti PP 46 tahun 2013.

Berdasarkan latar belakang yang telah diuraikan diatas dan pentingnya pemenuhan kewajiban pajak penghasilan bagi wajib pajak tersebut, maka penulis tertarik untuk menyusun penelitian dengan judul "Evaluasi Penerapan PPH Final PP 46 Tahun 2013 Pada Pedagang Tenant Metropolitan Mall Bekasi”

\section{LANDASAN TEORI}




\section{PPH FINAL PP 46 Tahun 2013}

Pengusahan menilai dimensi ketidakadilan pada PP 46 Tahun 2013 tentang Penghasilan usaha wajib pajak yang memiliki peredaran bruto tertentu. Direktorat Jenderal Pajak menerangkan sedikitnya ada 4 maksud dan 3 tujuan dari Peraturan Pemerintah tersebut diantaranya adalah PP 46 mempunyai maksud untuk:

1. Memberikan kemudahan dan penyederhanan aturan perpajakan;

2. Mengedukasi masyarakat untuk tertib administrasi;

3. Mengedukasi masyarakat untuk transparansi;

4. Memberikan kesempatan masyarakat untuk berkontribusi dalam penyelenggaraanNegara.

PP 46 juga memiliki tujuan untuk:

1. memberikan kemudahan masyarakat dalam melaksanakan kewajiban perpajakan;

2. Meningkatkan pengetahuan tentang manfaat perpajakan bagi masyarakat;

3. Terciptanya kondisi kontrol sosial dalam memenuhi kewajiban perpajakan.

Semua maksud dan tujuan tersebut dilaksanakan demi tercapainya satu hasil yang diharapkan direktorat Jenderal Pajak yaitu Penerimaan pajak meningkat sehingga kesempatan pemerintah untuk mensejahterakan rakyat juga menigkat.

Secara sederhana Peraturan ini dikenakan kepada wajib pajak yang peredaran brutonya tidak melebihi dari Rp 4,8 Milyar dalam 1 Tahun Pajak, adapun tarif yang dibebankan kepada wajib pajak ialah sebesar $1 \%$ dari Jumlah peredaran bruto selama satu bulan takwim.
Pajak ini diklasifikasikan kedalam PPh Final pasal 4 ayat (2), adapun dasar hukumnya adalah sebagai berikut :

1. Pasal 4 ayat (2) huruf e UU PPh :

Dengan menggunakan Peraturan

Pemerintah (PP dapat ditetapkan cara menghitung Pajak Penghasilan yang lebih sederhana dibandingkan dengan menggunakan UU PPh secara umum. Penyederhaanya yakni WP hanya menghitung dan membayar pajak berdasarkan peredaran bruto (omzet)

2. Pasal 17 ayat (7) UU PPh :

Pada intinya penerbitan PP 46 Tahun 2013 ditujukan terutama untuk kesederhanaan dan pemerataan dalam melaksanakan kewajiban perpajakan.

Dari segi Akuntansi, tentunya PP 46 Tahun 2013 ini menimbulkan adanya beberapa perubahan baik dalam pembukuan maupun dalam proses kepatuhan Pajak (Tax compliance) sebagai hasil disahkannya PP 46 Tahun 2013 tersebut yang diklasifikasikan sebagai $\mathrm{PPh}$ Pasal 4 ayat (2) dan bersifat final.

\section{Pemahaman Wajib Pajak Atas PP No. 46/2013}

Terdapat enam indikator dalam menilai pemahaman responden terhadap pajak yang diatur dalam PP No. 46/2013. Hasil statistik deskriptif menunjukkan bahwa pemahamana responden terhadap pajak PP No. 46/2013 adalah netral. Hal ini dibisa disimpulkan bahwa responden tidak terlalu mamahmi aturan tersebut namun mengetahuinya. Rata- rata skor untuk varibel ini adalah sebesar 2,9 dengan standar deviasi sebesar o,8. Dengan demikian pemahaman responden masih netral dengan tingkat keseragaman yang cukup seragam.

Implementasi Self Assesment System 
Di Indonesia telah diimplemtasikan sistem penilaian secara mandiri atau Self Assesment System. Terdapat lima indikator untuk mengatahui implemntasi Self Assesment System oleh responden terhadap perpajakan. Hasil penyebaran kuesioner menyebutkan bahwa rata-rata responden netral dalam menilai Self Assesment System. Rata-rata skor untuk Self Assesment System sebesar 2,8 dengan tingkat standar deviasi sebesar 0,7. Dengan demikian dapat disimpulkan bahwa responden menilai netral dengan seragam terhadap Self Assesment System Persepsi Wajib Pajak

Persepsi wajib pajak PP No. 46/2013 berdasarkan hasil pengisian kuesioner bahwa responden setuju dengan adanya PP No. 46/2013. Responden menilai peraturan tersebut lebih pasti dan tidak berblit-belit, dan lebih jelas. Berikut adalah skor jawaban responden untuk varibel persepsi jawib pajak atas PP No. 46/2013. Rata-rata skor untuk persepsi wajib pajak sebesar 3,8 dengan rata-rata standar deviasi atau penyimpangan sebedar o,6. Dengan demikian jawaban responden atas variabel persepsi wajib pajak seragam.

Sanksi Perpajakan

Skor sanksi perpajakan rata-rata sebesar 3,5 dengan standar deviasi 0,7. Hal ini dapat disimpulkan bahwa responden setuju atas sanksi perpajakan yang dikenakan kepada para wajib pajak berdasarkan peraturan yang ada. Dengan demikian responden juga memahami peraturan tersebut dan berusaha untuk mematuhinya. Berikut adalah statistic deskriptif untuk variabel sanksi perpajakan. Kepatuhan Wajib Pajak

Untuk mengetahui kepatuhan responden terhadap pajak digunakan sepuluh indikator. Hasil analisis deskriptif menunjukkan bawah rata-rata responden netral mematuhi kewajibannya membayar pajak. Dengan demikian dapat disimpulkan bahwa responden memiliki tingkat kepatuhan membayar pajak yang tidak tinggi dan juga tidak rendah. Hal ini bisa dipahami karena membayar pajak adalah merupakan sebuah pengorbanan, ada biaya yang harus dikeluarkan sehingga dapat mengurangi pendapatan responden. Namun disisi lain membayar pajak merupakan kewajiban yang harus dilakukan. Jika tidak maka akan menerima konsekuensi seperti dapat menghambat pada kelancaran usaha. berikut adalah tabel deskriptif jawaban responden pada variabel kepatuhan wajib pajak. Berdasarkan hasil perhitungan, rata-rata skor jawaban responden adalah 3,4 dengan katagori netral dan standar deviasi sebesar 0,8 . Semakin kecil standar deviasi maka keseragaman jawaban semakin tinggi.

\section{Pedagang UKM}

Wirausaha merupakan bidang usaha yang dapat dilakukan oleh siapa saja termasuk dapat dilakukan dengan latar belakang pendidikan apa saja. Mulai dari pendidikan terendah bahkan tidak berpendidikan sekalipun sampai dengan pendidikan tertinggi. Karakteristik ini juga dapat dilihat dari latar belakang pendidikan pada responden penelitian ini.

Mall merupakan tempat tenant menjual berbagai barang dagangan. Sehingga di Mall banyak jenis barang dagangan yang ditarwarkan. Seperti pakaian, elektronik, esesoris (perempuan), sepatu/tas dan lain sebagainnya. Toko yang sering dijumpai diataranya adalah toko pakaian, tas, dan sepatu, juga gadget.

Menurut pengamatan sementara Pedagang Tenant Metropolitan Mall Bekasi, ada indikasi penghindaran pajak 
denganmelakukan pengurangan terhadap penghasilan dengan bekerjasama dengan oknum tertentu, sehingga kemungkinan para pedagang tenant tersebut belum sepenuhnya patuh dan belum sepenuhnya memperhitungkan serta membayar pajak yang tidak sesuai dengan ketentuan perpajakan. Dengan demikian Penerimaan pajak tidak akan sesuai dengan target yang di harapkan pemerintah.

Dengan demikian mengingat di Metropolitan Mall Bekasi banyak pedagangpedagang tenant kemungkinan penghasilannya di bawah 4,8 Milyar, maka kami meneliti dari kepatuhan para tenant tersebut membayar pajak, dengan perhitungan sesuai dengan UndangUndang Perpajakan.

\section{Kerangka Penelitian}

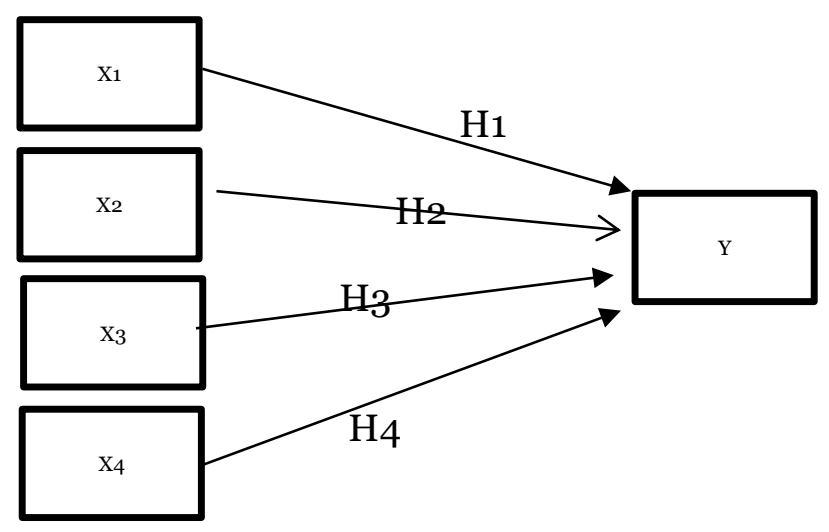

Gambar. 1. Kerangka Penelitian

Hypothesis

H1: Diduga ada pengaruh pemahaman wajib pajak terhadap kepatuhan pajak;

H2: Diduga ada pengaruh implementasi self assesment system terhadap kepatuhan pajak;

H3: Diduga ada pengaruh persepsi wajib pajak terhadap kepatuhan pajak;

H4: Diduga ada pengaruh sanksi pajak terhadap kepatuhan pajak.

\section{METODE PENELITIAN}

Pendekatan penelitian yang digunakan adalah pendekatan kuantitatif dengan uji validitas, reliabilitas, normalitas, heterokedastisitas, multikolinearitas dan uji t.

Jenis data yang digunakan dalam penelitian ini, yaitu data primer. Data primer yaitu data yang berasal langsung dari sumber data yang dikumpulkan secara khusus dan berhubungan langsung dengan permasalahan yang diteliti (Cooper dan Emory, 1996 dalam Jatmiko, 2006). Sumber data primer pada penelitian ini diperoleh langsung dari para Wajib Pajak. Data ini merupakan kuesioner yang telah diisi oleh para Wajib Pajak yang menjadi responden terpilih dalam penelitin ini.

Jenis penelitian yang digunakan adalah penelitian deskriptif analitis. Penelitian deskriptif analitis adalah suatu jenis penulisan yang berusaha menggambarkan dan menganalisis data yang diperoleh selama proses penelitian serta membuat interpretasi dari data menjadi wawancara dan kesimpulan dalam berpikir logis, praktis dan teoritis. Dalam penelitian ini, pengumpulan data berdasarkan studi literature dan peraturan perpajakan yang berlaku.

Pengumpulan data primer dilakukan dengan petode survei menggunakan media angket (kuesioner). Sejumlah pertanyaan diajukan kepada responden dan kemudian responden diminta menjawab sesuai dengan pendapat mereka. Untuk mengukur pendapat responden digunakan skala likert lima angka yaitu angka 5 untuk pendapat sangat setuju (SS) dan angka 1 untuk sangat tidak setuju (STS). Data primer diuji dengan 
menggunanak uji validitas dan reliabilitas. Teknik analisis data menggunakan model regresi linear berganda.

\section{HASIL PENELITIAN PEMBAHASAN}

\section{Profil Responden}

Respoden dalam penelitian ini adalah para pedagang (tenant) yang berada di Mall Metropolitan, Bekasi - Jawa Barat. Kuesioner disebarkan ke responden sebanyak 100 kuesioner, namun setelah dilakukan pengecekan data, kuesioner yang layak untuk dilakukan pengujian dalam penelitian ini adalah sebanyak 92 kuesioner. Dengan demikian total responden dalam penelitian ini sebanyak 92 orang.

Dilihat dari jenis kelaminnya, respoden penelitian ini terdiri dari 41 orang atau 45 persen adalah berjenis kelamin lakilaki. Sedangkan sisanya sebanyak 51 orang atau 55 persen adalah perempuan.

Pendidikan respoden terdiri dari level pendidikan sekolah menengah pertama (SMP) sebanyak 5 orang atau 5 persen, responden dengan pedidikan SMA sebanyak 30 orang atau 33 persen. Responden dengan tingkat pendidikan Diploma sebanyak 20 orang atau 22 persen. Sedangkan responden dengan pendidikan sarjana sebanyak 25 orang atau 27 persen. Sementara lainnya atau tidak menjawab sebanyak 12 orang atau 13 persen.

Dilihat dari jenis usahanya (barang dagangan), responden dalam penelitian ini terdiri dari 23 outlet/toko pakaian atau sebanyak 25 persen. Toko sepatu/sandal sebanyak 18 toko atau 19 persen. Toko tas sebanyak 20 outlet atau 22 persen. Toko jama tangan sebanyak 10 toko atau 11 persen. Sementara toko asesoris atau pernak-pernik sebanyak 9 outlet atau 9 persn. Toko tekstil sebanyk 4 toko atau 4 persen. dan toko gadget atau komputer sebanyak 7 outlet atau 8 persen. Sementara lainnya, tidak teridentifikasi, sebanyak 2 outlet atau 2 persen.

Dilihat dari lamanya usaha, sebanyak 48 responden atau 53 persen telah memiliki usaha satu sampai dengan lima tahun. Terdapat 31 responden atau 34 persen memiliki usaha di atas lima tahun. Sementara responden yang memiliki usaha kurang dari satu tahun sebanyak 9 responden atau 10 persen. Sedangkan responden yang baru memulai usaha atau di bawah satu tahun sebanyak 3 orang atau 3 persen.

Dilihat dari omzetnya pertahun, sebanyak 59 orang/usaha atau 49 persen memiliki omzet kurang dari $\mathrm{Rp}$ 300.000.000; Responden yang memiliki omzet diataran $\mathrm{Rp} 300.000 .000$ dan 2,5 milyar sebanyak 21 orang/usaha atau 23 persen. Sementara responden yang memiliki omzet sebesar di atas 2,5 milyar sampai dengan 50 milyar sebanyak 3 orang/usaha atau 3 persen. Sedangkan responden yang tidak menjawab sebanyak 9 orang atau 10 persen. Dari data ini dapat disimpulkan bahwa dilihat dari omzetnya, pelaku usaha di Mall Metropolitan ini adalah usaha mikro dan kecil.

Dilihat dari jumlah tenaga kerja yang terlibat dalam usaha responden. Terdapat 71 usaha atau 77 persen yang mempekerjakan karyawan tidak lebih dari empat orang

Jumlah responden 95 orang terdiri dari 56 perempuan dan 39 laki-laki dengan tingkat pendidikan SLTA 54 orang, 28 diploma dan sarjana serta 13 magister. Responden ditinjau dari umur terdiri dari: 17 sampai dengan 30 tahun sebanyak 58; 30 
sampai 43 tahun dengan total 24; dan 43 sampai 55 tahun sebanyak 13. Responden dalam hal status kepegawaian terdiri dari: pegawai tetap yang berjumlah 33 orang; Ada 42 karyawan tidak tetap dan 20 karyawan harian lepas. Terdapat 15 atau 16 persen yang mempekerjakan kayawan sebanyak lima sampai dengan Sembilan orang. Tidak ada yang memperkejakan atau memiliki karyawan di atas 20 orang. Sementara responden yang tidak menjawab sebanyak 6 orang atau 7 persen.

Pada tahap ini data dijelaskan tentang gambaran jawaban responden atas pertanyaan yang diajukan dalam kuesioner. Data dianalisis berdasarkan pada mean atau rata-rata jawaban responden. Meanatau rata-rata jawaban menggambarkan mayoritas responden dalam menjawab pertanyaan, apakah setuju (S), sangat setuju (SS), netral (N), tidak setuju (TS), atau sangat tidak setuju (STS). Apabila skor jawaban responden $4,4-5$ sagat setuju (SS), 3,5-4,2 maka setuju (S). Jika 2,7 - 3,4 maka netral (N), 1,9-2,6 tidak setuju (TS), dan skor 1 - 1,8 sangat tidak setuju (STS). Berikut adalah jawaban pada setiap variabel.

\section{Uji Validitas}

Uji validitas dilakukan untu melihat apakah setiap item pertanyaan dalam setiap variabel penelitian. Pengujian ini juga dilakukan sebagai syarat untuk dilakukan pengujian-pengujian data selanjutnya. Berikut adalah hasil uji validitas untuk item pertanyaan pada variabel X1. Dari hasil pengujian dapat disimpulkan bahwa semua item pertanyaan pada variabel $\mathrm{X} 1$ adalah valid. Karena nilai korelasi lebih dari 0,5. Uji validitas untuk variabel $\mathrm{X} 2$ menunjukkan item pertanyaan dalam veriabel ini valid. Karena nilai korelasi lebih dari 0,5. Uji validitas untuk variabel $\mathrm{X}_{3}$ menunjukkan item pertanyaan dalam veriabel ini valid.
Karena nilai korelasi lebih dari o,5. Berikut adalah hasil uji validitas item pertanyaan pada variabel $\mathrm{X}_{3}$ dengan menggunakan SPSS. Uji validitas untuk variabel $\mathrm{X}_{4}$ menunjukkan item pertanyaan dalam veriabel ini valid. Karena nilai korelasi lebih dari 0,5. Berikut adalah hasil uji validitas item pertanyaan pada variabel X4 dengan menggunakan SPSS. Uji validitas untuk variabel $Y$ menunjukkan item pertanyaan dalam veriabel ini valid. Karena nilai korelasi lebih dari 0,5 . Berikut adalah hasil uji validitas item pertanyaan pada variabel Y dengan menggunakan SPSS.

\section{Uji Reliabilitas}

Uji reliabilitas bertujuan untuk mengetahui apakah alat pengumpul data pada dasarnya menunjukkan tingkat ketepatan, keakuratan, kestabilan atau konsistensi alat tersebut dalam mengungkapkan gejala tertentu dari sekelompok individu walaupun pada waktu yang berbeda.Uji validitas untuk setiap variabel dalam penelitian ini dapat dilihat pada tabel berikut:

Tabel 1. Uji reliabilitas

\begin{tabular}{cc}
\hline Variabel & Cronbach's Alpha \\
\hline $\mathrm{X} 1$ & 0,985 \\
\hline $\mathrm{X} 2$ & 0,823 \\
\hline $\mathrm{X} 3$ & 0,834 \\
\hline $\mathrm{X} 4$ & 0,861 \\
\hline $\mathrm{Y}$ & 0,952
\end{tabular}

Sumber: data diolah, 2018

\section{Uji Normalitas}

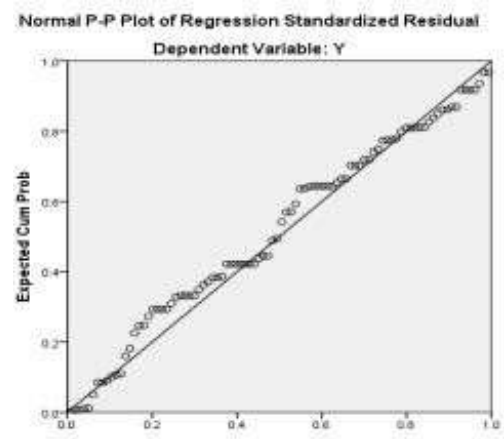


Gambar 2. Uji Normalitas dengan P-P Plot Sumber: Data Diolah, 2018

Berdasarkan gambar 2 di atas dapat dilihat sebaran titik-titik. Karena sebaran titik-titik mendekati garis lurus (diagonal), maka dapat disimpulkan bahwa data dalam penelitian berdistribusi normal.

\section{Uji Multikolinearitas}

Berdasarkan tabel 2 di bawah ini, maka uji multikolinearitas terpenuhi karena semua nilai tolerance lebih besar dari o,1atau semua nilai VIF lebih kecil dari 10. Dengan demikian salah satu uji asumsi klasik, yaitu uji multikolinearitas juga telah terpenuhi. Jika nilai tolerance atau VIFlebih besar dari o,1atau nilai VIF lebih kecil dari 10 maka tidak terjadi multikolinearitas. Sebaliknya apabila lebih kecil dari 0,1 atau nilai VIF lebih besar dari 10 maka terjadimultikolinearitas.

Tabel 2. Uji Multikolinearitas

\begin{tabular}{lll}
\hline & Collinearitity & Statistics \\
\hline & Tolerance & VIF \\
\hline $\mathrm{X} 1$ & 0,951 & 1,052 \\
\hline $\mathrm{X} 2$ & 0,946 & 1,057 \\
\hline $\mathrm{X} 3$ & 0,968 & 10033 \\
\hline $\mathrm{X} 4$ & 0,951 & 1,052 \\
\hline
\end{tabular}

Sumber: Data Diolah, 2018

Tabel 3. Uji Heterokedastisitas

\begin{tabular}{lll}
\hline & Beta & Sig \\
\hline Constant & & 0,000 \\
\hline $\mathrm{X} 1$ & 0,167 & 0,111 \\
\hline $\mathrm{X} 2$ & 0,255 & 0,076 \\
\hline $\mathrm{X} 3$ & 0,106 & 0,306 \\
\hline $\mathrm{X} 4$ & 0,067 & 0,522 \\
\hline
\end{tabular}

Sumber: Data Diolah, 2018

Berdasarkan tabel 3 diatas ini, apabila nilai signifikasi lebih besar dari 0,05 maka tidak terjadi heteroskedasatisitas. Sebaliknya apabila nilai signifikasi kurang dari 0,05 maka terjadi heteroskedastisitas. Nilai sig. lebih besar dari 0,05, sehingga dapat simpulkan bahwa data pada penelitian ini tidak terjadi heteroskedastisitas atau salah satu asumsi klasik terpenuhi.

Pada tabel 4 hipotesis pertama diperoleh nilai $t$ hitung untuk variabel pamahaman wajib pajak (X1) sebesar 1,612. Nilai tersebut lebih kecil dari t tabel 1,996 yang berarti bahwa tidak ada pengaruh yang signifikan antara pemahaman wajib pajak terhadap kepatuhan pajak.

Pada hipotesis kedua diperoleh nilai t hitung untuk variabel Implementasi self assesment system (X2) sebesar 2,451 lebih besar dari t tabel 1,996. Dengan demikian dapat disimpulkan bahwa Implementasi self assesment system berpengaruh positif signifikan terhdap kepatuhan terhadap pajak.

Pada hipotesis ketiga diperoleh nilai $\mathrm{t}$ hitung 1,029 untuk variabel persepsi wajib pajak (X3) nilai t hitung sebesar 1,029 lebih kecil dari t tabel 1,996. Sehingga dapat disimpulkan bahwa persepsi wajib pajak tidak memiliki pengaruh terhadap kepatuhan pajak.

Pada hipotesis keempat diperoleh nilai signifikasi variabel sanksi perpajakan (X4) dengan t hitung sebesar o,643 lebih kecil dari t tabel 1,996 menandakan bahwa sanksi perpajakan tidak berpengaruh terhadap kepatuhan pajak.

Tabel 4. Uji T

Standardized Coeffficients

\begin{tabular}{llll}
\hline & Beta & $\mathrm{t}$ & Sig \\
\hline Constant & & 3,718 & 0,000 \\
\hline $\mathrm{X} 1$ & 0,167 & 1,612 & 0,011 \\
\hline $\mathrm{X} 2$ & 0,255 & 2,451 & 0,016 \\
\hline $\mathrm{X} 3$ & 0,106 & 1,029 & 0,006 \\
\hline $\mathrm{X} 4$ & 0,067 & 0,643 & 0,022 \\
\hline
\end{tabular}

Sumber: Data Diolah, 2018

\section{Pembahasan}


Nilai Sig. untuk variabel pamahaman wajib pajak (X1) t hitung sebesar 1,612. Nilai tersebut lebih kecil dari t tabel 1,996 yang berarti bahwa tidak ada pengaruh yang signifikan antara pemahaman wajib pajak terhadap kepatuhan pajak. Semakin tinggi atau rendahnya pemahaman wajib pajak maka tidak akan berpengaruh terahadap kepatuhan wajib pajak membayar pajaknya.

Nilai signifikasi untuk variabel implementasi self assesment system (X2) sebesar 2,451 lebih besar dari t tabel 1,996. Dengan demikian dapat disimpulkan bahwa implementasi self assesment system berpengaruh positif signifikan terhdap kepatuhan terhadap pajak. Semakin mudah implementasi self assesment system maka tingkat kepatuhan wajib pajak juga akan tinggi.

Variabel persepsi wajib pajak (X3) nilai t hitung sebesar 1,029 lebih kecil dari 1, 996. Sehingga dapat disimpulkan bahwa persepsi wajib pajak tidak memiliki pengaruh terhadap kepatuhan pajak. Semakin tinggi atau rendahnya pemahaman persepsi wajib pajak maka tidak akan berpengaruh pada kepatuhan terhadap pajak.

Nilai signifikasi variabel sanksi perpajakan (X4) dengan $t$ hitung sebesar o,643 lebih kecil dari $t$ tabel 1,996 menandakan bahwa sanksi perpajakan tidak berpengaruh terhadap kepatuhan pajak. Semakin tinggi atau rendahnya sanksi yang diterapkan, maka tidak akan berpengaruh terhadap kepatuhan wajib pajak.

\section{KESIMPULAN}

Tidak ada pengaruh yang signifikan antara pemahaman wajib pajak terhadap kepatuhan pajak. Semakin tinggi atau rendahnya pemahaman wajib pajak maka tidak akan berpengaruh terahadap kepatuhan wajib pajak membayar pajaknya. Implementasi Self Assesment System berpengaruh positif signifikan terhdap kepatuhan terhadap pajak. Semakin mudah implementasi Self Assesment System maka tingkat kepatuhan wajib pajak juga akan tinggi. Persepsi wajib pajak tidak memiliki pengaruh terhadap kepatuhan pajak. Semakin tinggi atau rendahnya pemahaman persepsi wajib pajak maka tidak akan berpengaruh pada kepatuhan terhadap pajak. Tidak berpengaruh terhadap kepatuhan pajak. Semakin tinggi atau rendahnya sanksi yang diterapkan, maka tidak akan berpengaruh terhadap kepatuhan wajib pajak.

\section{Daftar Pustaka}

Agung, Mulyo, (2009). Perpajakan Indonesia. Jakarta: Seri PPN, PPN BM dan PPh Badan.

Jakarta. Perpajakan Indonesia: Teori dan Aplikasi. Jakarta: Mitra Wacana Media

Direktorat Jenderal Pajak, (2007). UndangUndang Republik Indonesia Nomor 6 Tahun 1983 tentang ketentuan umun dan tata cara perpajakan sebagaimana telah diubah terakhir dengan undang-undang no 28 tahun 2007

Direktorat Jenderal Pajak, (2008). UndangUndang Republik Indonesia Nomor 36 Tahun 2008 tentang perubahan keempat atas undang undang nomor 7 tahun 1983 tentang Pajak Penghasilan

Mardiasmo, (2009). Perpajakan. Yogyakarta: Penerbit Andi

Republik Indonesia, (2013). Peraturan Pemerintah No 46 Tahun 2013 
tentang Pajak Penghasilan dari Usaha yang Diterima atau Diperoleh Wajib Pajak yang Memiliki Peredaran Bruto Tertentu

Resmi, Siti, (2014). Perpajakan Teori dan Kasus Edisi 4. Jakarta: 94 Tim Penyusun.

Direktorat Jenderal Pajak, Oasis Pemotongan dan Pemungutan PPh Revisi 2013. Jakarta. Sugiyono, 2009. Metode Penelitian Kuantitatif Kualitatif dan R\&D. Bandung. Alfabeta Waluyo, 2013. Perpajakan Indonesia Edisi 11. Jakarta: Salemba Empat 